\title{
Detecting the long-term impacts from climate variability and increasing water consumption on runoff in the Krishna river basin (India)
}

\author{
L. M. Bouwer ${ }^{1}$, J. C. J. H. Aerts ${ }^{1}$, P. Droogers ${ }^{2}$, and A. J. Dolman ${ }^{3}$ \\ ${ }^{1}$ Institute for Environmental Studies, Faculty of Earth and Life Sciences, Vrije Universiteit, Amsterdam, The Netherlands \\ ${ }^{2}$ FutureWater, Wageningen, The Netherlands \\ ${ }^{3}$ Department of Hydrology and Geo-environmental Sciences, Faculty of Earth and Life Sciences, Vrije Universiteit, \\ Amsterdam, The Netherlands
}

Received: 6 March 2006 - Published in Hydrol. Earth Syst. Sci. Discuss.: 4 July 2006

Revised: 5 September 2006 - Accepted: 26 September 2006 - Published: 4 October 2006

\begin{abstract}
Variations in climate, land-use and water consumption can have profound effects on river runoff. There is an increasing demand to study these factors at the regional to river basin-scale since these effects will particularly affect water resources management at this level. This paper presents a method that can help to differentiate between the effects of man-made hydrological developments and climate variability (including both natural variability and anthropogenic climate change) at the basin scale. We show and explain the relation between climate, water consumption and changes in runoff for the Krishna river basin in central India. River runoff variability due to observed climate variability and increased water consumption for irrigation and hydropower is simulated for the last 100 years (1901-2000) using the STREAM water balance model. Annual runoff under climate variability is shown to vary only by about $14-34$ millimetres (6-15\%). It appears that reservoir construction after 1960 and increasing water consumption has caused a persistent decrease in annual river runoff of up to approximately $123 \mathrm{~mm}(61 \%)$. Variation in runoff under climate variability only would have decreased over the period under study, but we estimate that increasing water consumption has caused runoff variability that is three times higher.
\end{abstract}

\section{Introduction}

Human induced climate change, as well as natural climate variability, may have profound impacts on freshwater resources in many areas (Arnell et al., 2001). However, these impacts may be obscured by non-climatic factors, often an-

Correspondence to: L. M. Bouwer

(laurens.bouwer@ivm.falw.vu.nl) thropogenic in origin. Therefore, the relative impact of climate compared to non-climatic factors is important when studying the relation between climate and water resources availability. Non-climatic factors may be land use and land cover change. In particular developments in water storage in reservoirs and consumption for irrigation and industry cause increased evaporation and substantial effects on river runoff (e.g. Döll and Siebert, 2002; De Rosnay et al., 2003; Haddeland et al., 2006). Water consumption may affect the annual water budget, while the structures that capture water such as dams and reservoirs may change the patterns of the annual hydrological cycle. The global amount of water consumed for agriculture has been estimated to have roughly doubled between 1900 and 1980 (Falkenmark and Lannerstad, 2005). Water has therefore been identified a critical factor for reaching the Millennium Development Goals (Rockström et al., 2005), and further assessment of shifts in water availability is needed.

Several studies have been devoted to either the impact of climate conditions or environmental and human use of water availability. Using hydrological models, it is possible to make a distinction between pristine catchment conditions and the effects of environmental changes (e.g. Letcher et al., 2001). Recent global studies on the effects of water storage and consumption have shown dramatic effects on the frequency of low flows and downstream water resources and services (Syvitski et al., 2005; Nilsson et al., 2005). Examples include the reduction of the amount of total river runoff, the reduction in peak flow intensity, reduction in sediment transport, and changes in water quality, with consequences for downstream river morphology and ecology. Regional studies show similar trends. For instance, Magilligan et al. (2003) estimated that the peak discharges occurring every two years have decreased by about $60 \%$ for a number

Published by Copernicus GmbH on behalf of the European Geosciences Union. 


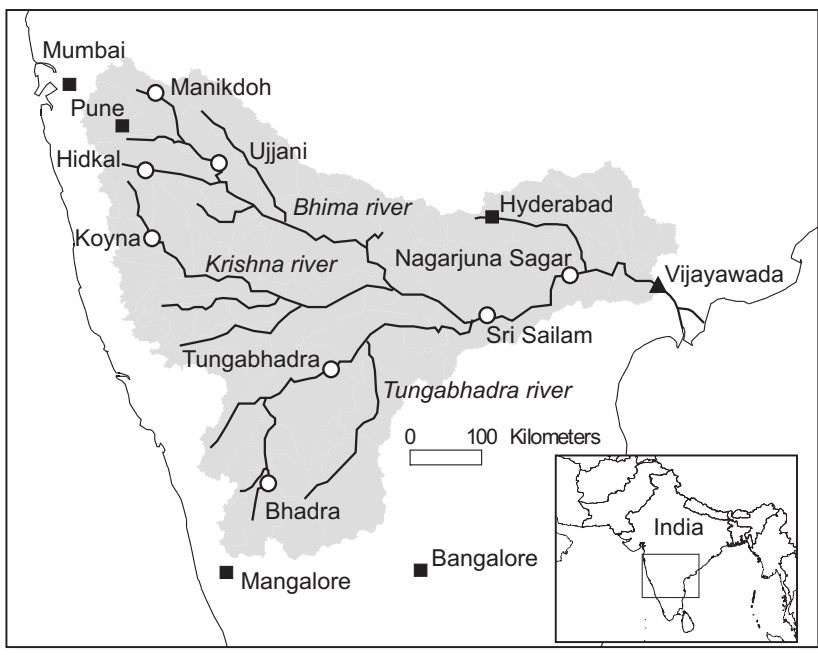

Fig. 1. Map of the Krishna river basin with its main tributaries, major cities (squares) and the discharge gauging station at Vijayawada (triangle) at the lower end of the river. The open circles indicate the locations of the eight largest reservoirs in the basin.

of river basins in the United States. Schreider et al. (2002) showed that due to the construction of small farm dams in Australia small but detectable changes can occur in the daily discharges. It has thus been argued that natural processes are no longer the sole influence on river systems: anthropogenic influences currently dominate (Meybeck, 2003).

Some researchers have approached these anthropogenic influences by using the green- and blue water concept. Green water refers to the amount of available freshwater that is used for evaporation in natural or agricultural vegetation, which is consumptive use, whereas blue water refers to the amount of water that is unaffected or remains as return flow. The blue water flow is important for downstream water availability, and it has been proposed that a certain requirement for minimum flow exists for ecological sustainability (Tharme, 2003). However, while an assessment of "green" and "blue" water flows is important for proper decisions in water resources management, the total amount of available freshwater from which allocations can be made is not constant over time, mostly because of variations in climate. It appears, however, that very few studies pay attention to the combined effect of natural climate variability, climate change and anthropogenic impacts (e.g. Changnon and Demissie, 1996). It also happens that studies on water availability have used relatively short time intervals or concentrate on the average climate state and effects at the global or regional scale (e.g. Alcamo et al., 1997). Vörösmarty et al. (2000) compared the impacts from climate change and population growth and concluded that average climate change is likely to have a minor impact on water resources. However, they ignored the potential impacts that changes in year-to-year variability of climate may have. Most climate trend detection analyses so far have focussed on the analysis of the mean river runoff and not on changes in runoff variability (for an overview see Kundzewicz and Robson, 2004). The assessment of historic high and low flows as demonstrated by Burn and Hag Elnur (2002), or statistical analyses applied to climate change scenarios as demonstrated for low flows by Arnell (2003), have shown the impact of climate variability on the variability of river runoff. Studies of runoff effects caused by both climate variability and basin developments should consider long and discrete periods, preferably more than 50 years in order to capture multi-decadal variability of climate and river runoff.

The main goal of the present research was to develop and test a method to separate the relative impact of observed climate variability (which in this study is defined to include both natural variability and anthropogenic climate change) versus human water use on river runoff variability at the river basin scale. We have limited ourselves to studying the impacts of increasing water consumption for irrigation and evaporation losses from water storage for hydropower production on the annual and seasonal river runoff over a period of 100 years. These factors were studied in the arid region of the Krishna river basin, which is located in central India. The objectives of this study were to:

- Assess and present statistics of the variation in climate and river discharges, in particular changes in precipitation and annual river runoff;

- Calibrate and validate a spatial hydrological model in order to simulate monthly river runoff over a 100 -year period under climate variability, with and without accounting for changes in water consumption;

- Quantify changes in annual and seasonal river runoff and runoff variability over 100 years by comparing observed and modelled monthly river runoff;

- Determine the relative influence of variation in climate versus increasing water consumption on annual basin river runoff and runoff variability.

\section{Study area and data}

\subsection{The Krishna river basin}

The Krishna river basin is the second largest river in peninsular India and stretches over an area of $258948 \mathrm{~km}^{2}$. The basin is located in the states of Karnataka $\left(113271 \mathrm{~km}^{2}\right)$, Andhra Pradesh $\left(76252 \mathrm{~km}^{2}\right)$ and Maharashtra $\left(69425 \mathrm{~km}^{2}\right)$. The basin represents almost $8 \%$ of surface area of the country of India and is currently inhabited by 67 million people. The major tributaries of the river include the Bhima River in the north and the Tungabhadra River in the south (Fig. 1). The river terminates at the $\mathrm{Kr}$ ishna delta in the Bay of Bengal. The climate in the basin is characterised by sub-tropical conditions with considerable 
rainfall in the mountains of the Western Ghatts and arid conditions in the basin interior. Total annual rainfall today averages $835 \mathrm{~mm}$, while the annual average temperature reaches $26.7^{\circ} \mathrm{C}$. Rainfall over India is highly variable due to the intraseasonal and inter-annual variability of the South-West monsoon (June to September) and the North-East monsoon (October to November), leading to alternating drier and wetter conditions on the Indian continent (Krishnamurthy and Shukla, 2000; Munot and Kothawale, 2000). A dry season occurs during the period December-May.

Failing monsoons have often resulted in considerable declines in water availability and consequently led to increasing political tensions between the states. One of the driest recent episodes in Central India occurred in 1972 (see Fig. 2). Over 100 million people in India were affected as crops failed (http://www.em-dat.net). In 1973 the water allocation between the three riparian states of Maharashtra, Karnataka and Andhra Pradesh was settled in a water disputes act. Declines in water availability also impact on water quality. Chloride concentrations in the Krishna River, for instance, are highly correlated to total amounts of river runoff (Sekhar and Indira, 2003). It has also been shown that sediment loads of the $\mathrm{Kr}$ ishna River have decreased over time (Ramesh and Subramania, 1988).

For many centuries small reservoirs, locally known as tanks, have been constructed to conserve and utilise water, and under British rule new canals were created, old tanks restored and new tanks built (Wallach, 1985). But the major reservoirs and canal systems now present in the basin were constructed during the second half of the 20th century for irrigation purposes and hydropower generation. Since the independence of India in 1947 the construction of reservoirs started to take off rapidly (Wallach, 1984). All large reservoirs with a storage capacity of more than $10^{9} \mathrm{~m}^{3}$ were built after 1953. The locations of the eight largest reservoirs in the basin are depicted in Fig. 1. These reservoirs were constructed between 1953 and 1988, and together they account for $26.610^{9} \mathrm{~m}^{3}$ or $80 \%$ of the capacity of large reservoirs in the basin. The storage capacity in the Krishna river basin is exceeded in India only by the capacity in the Ganges river basin. The benefits of water storage and redirection are clear: the current area of land that is being irrigated amounts to about $3.2 \times 10^{6}$ ha and a total of 1947 MW of electricity is produced annually.

\subsection{Climate and river runoff data}

Climate data were retrieved from the global TS 2.0 dataset from the Climatic Research Unit, which covers the entire world for the period $1901-2000$ on a 0.5 by 0.5 degree grid (Mitchell and Jones, 2005). Although this climate data has not been corrected for ambient factors, such as urban development or land use change, it is the most comprehensive climate dataset presently available and previous versions have often been used for studying the hydrological cycle.
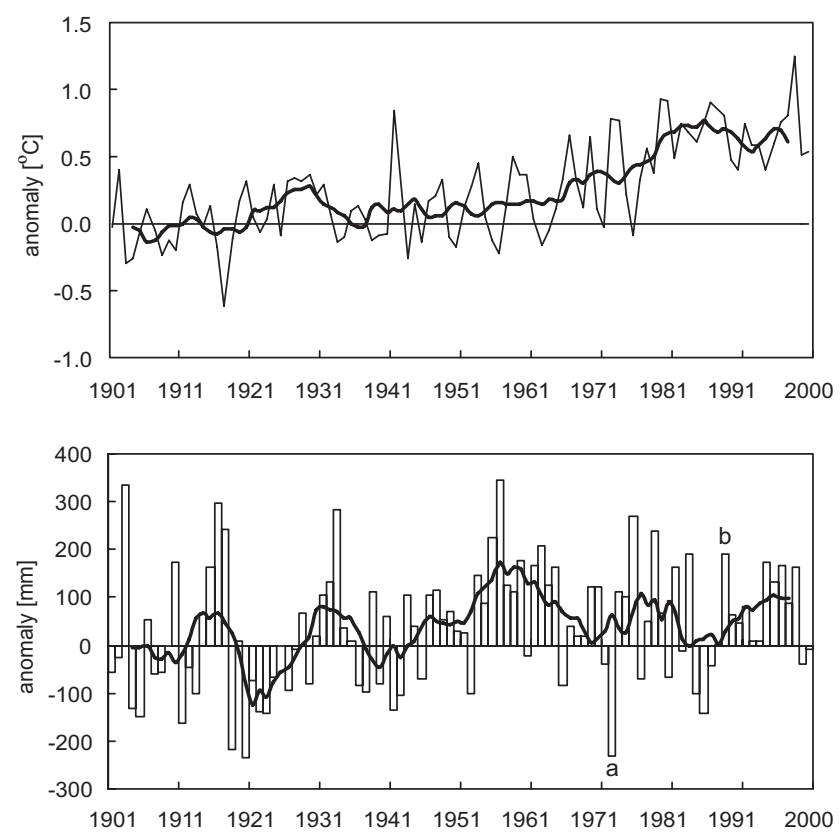

Fig. 2. Temperature (top) and precipitation (bottom) anomalies and their seven-year moving averages in the Krishna River Basin, relative to the period 1901-1915. In the lower graph, a and b designate a dry and a wet year, for which the spatial patterns of effective precipitation are plotted in Fig. 5.

Data on average monthly river discharges were taken from the RivDIS database available at http://www-eosdis.ornl. gov/rivdis/STATIONS.HTM (Vörösmarty et al., 1998) for the downstream station at the city of Vijayawada (Global Runoff Data Centre station number 2854300) close to the mouth of the river; see Fig. 1. The data covers the period 1901-1979, with no data during the period 1961-1964 and for the year 1975. Additional discharge data for the period 1989-1999 were collected from yearbooks of the Indian Central Water Commission.

\section{Trends in climate, peak runoff and reservoir develop- ment}

The climate data, discharge data and data on reservoir construction were investigated in order to assess what determines the runoff of the Krishna river basin. We considered periods of 15 years in order to be able to determine changes between a number of coherent climatic periods.

In Fig. 2 the temperature and precipitation anomalies in the Krishna river basin are given as deviations from the 15-year period of 1901-1915. During this period the average annual total amount of precipitation was $765 \mathrm{~mm}$, while the average annual temperature was equal to $26.0^{\circ} \mathrm{C}$. Variations between years and decades can clearly be observed. The data indicates that the average annual temperature increased by about $0.7^{\circ} \mathrm{C}$, from $26.0^{\circ} \mathrm{C}$ over the period $1901-1915$ to $26.7^{\circ} \mathrm{C}$ 


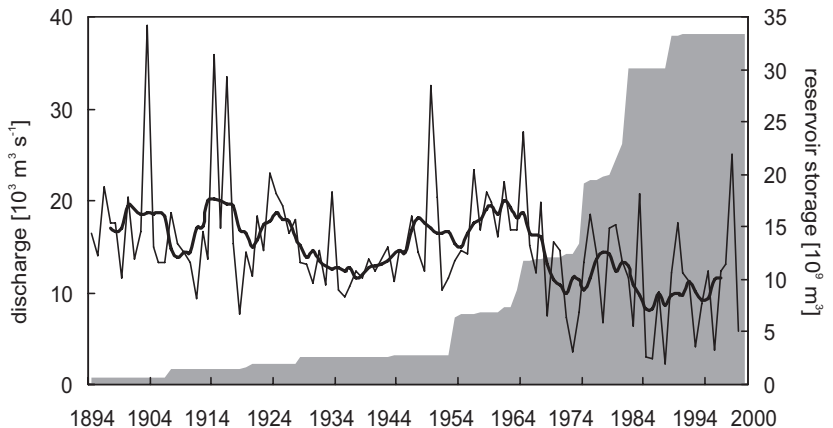

Fig. 3. Annual downstream peak discharge values (daily) over the period 1894-1999 (line), its seven-year moving average and the cumulative reservoir storage capacity (shaded area) of reservoirs larger than $10^{9} \mathrm{~m}^{3}$ in the Krishna river basin over the period 1894 2000. Peak discharge data were obtained from Rodier and Roche, 1984; Herschy, 2003; updated with CWC data for 1996-1999.

over the period 1986-2000. Average total annual precipitation increased slightly, by $9 \%$ between the same periods, from 765 to $835 \mathrm{~mm}$.

Observed discharge data were converted from cubic metre per second into runoff in millimetres per month, using the basin size as reported by Vörösmarty et al. (1998). The storage capacity of reservoirs larger than $10^{6} \mathrm{~m}^{3}$ has increased considerably after 1953, as can be seen from Fig. 3. The major reservoirs in the basin account for a storage capacity of $34.5 \times 10^{9} \mathrm{~m}^{3}$. An additional volume is present in numerous smaller tanks and barrages spread out over the area. The height of the annual peak discharge has decreased from about 1969 onward; when the seven-year moving average of the peak discharge drops below the long-term minimum (Fig. 3). The decreased downstream river runoff coincides with the rapid increase in reservoir storage capacity during the $1950 \mathrm{~s}$ and 1960s.

\section{Estimating changes in monthly runoff}

From Figs. 2 and 3, the question arises of how much water would have been available without reservoir development, and what difference between present and a hypothetical pristine situation in monthly and seasonal river runoff can be detected. For these purposes, a water balance model was developed to simulate monthly river runoff under observed climate variability and changes in water consumption. Variations of monthly and seasonal river runoff are important for the planning and management of agriculture, irrigation and hydropower production.

\subsection{The STREAM model}

The STREAM model (Aerts et al., 1999) is a spatial water balance model based on the formulation of the RHINEFLOW model (Van Deursen and Kwadijk, 1993). This model
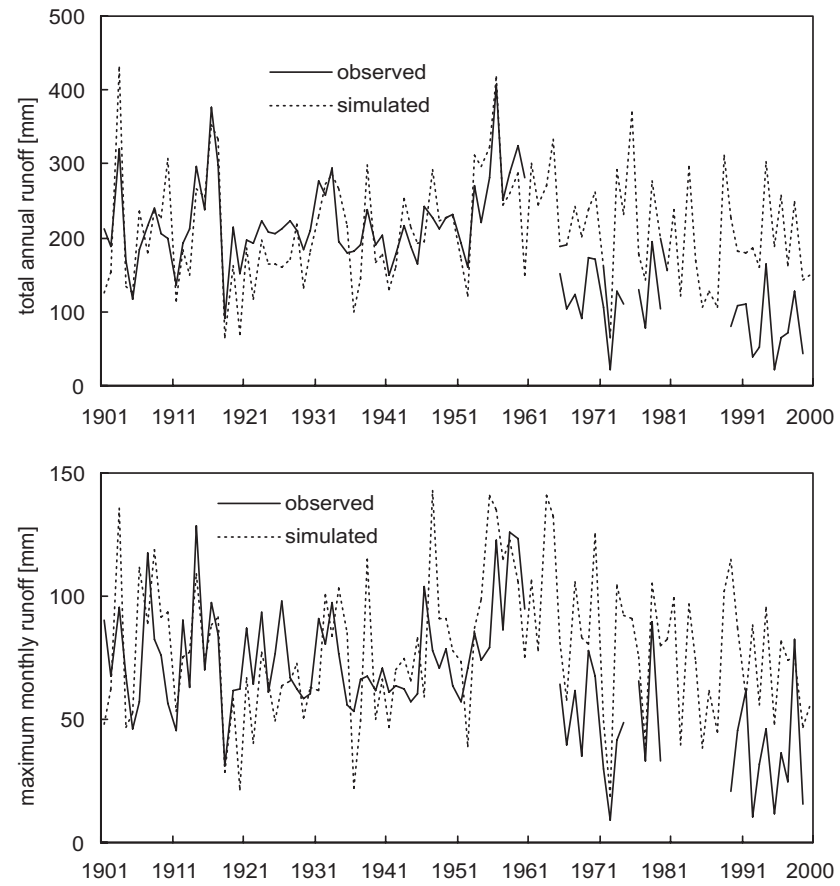

Fig. 4. Simulation model results for the period 1901-2000 compared to the observed total annual river runoff (top) and maximum monthly river runoff (bottom).

calculates water availability and river runoff on the basis of temperature and precipitation data and a number of land surface characteristics. Other factors that may influence in particular evaporation, such as radiation, wind speed and humidity, are not included in the model. Radiation is included indirectly through temperature. The STREAM model for the Krishna river basin uses geographical information system (GIS) data at a spatial resolution of 3 by $3 \mathrm{~km}$ and at a monthly time-step. Although the climate data has a lower spatial resolution, some of the other input data has a finer resolution (soil water holding capacity and land-use types; see Appendix A). The water balance is calculated for each grid-cell using a direct runoff, soil water and groundwater component (see Appendix A). The STREAM model has been successfully applied in various forms for climate and hydrology studies in a number of river basins with similar size and characteristics as the Krishna river basin (Van Deursen and Kwadijk, 1994; Aerts et al., 1999; Aerts et al., 2000; Middelkoop et al., 2001; Winsemius et al., 2006). These studies have confirmed that a monthly time step is sufficient for detecting decadal, inter-annual and seasonal changes in the hydrological cycle, such as those caused by water consumption and climatic change. The spatial resolution of 3 by $3 \mathrm{~km}$ is sufficient to analyse large-scale patterns, as the basin is approximately $260000 \mathrm{~km}^{2}$ in size and since the climate data is limited to a spatial resolution of 0.5 by 0.5 degrees. 
Table 1. Observed average amount of annual precipitation and its coefficient of variation, observed and simulated total average annual river runoff (in millimetres), their standard deviations $(S D)$, coefficients of variation $(C V)$ and model efficiency coefficients $\left(R^{2}\right)$ for the different periods. $n$ designates the number of months that were used to calculate the $C V$ and $R^{2}$ of the runoff.

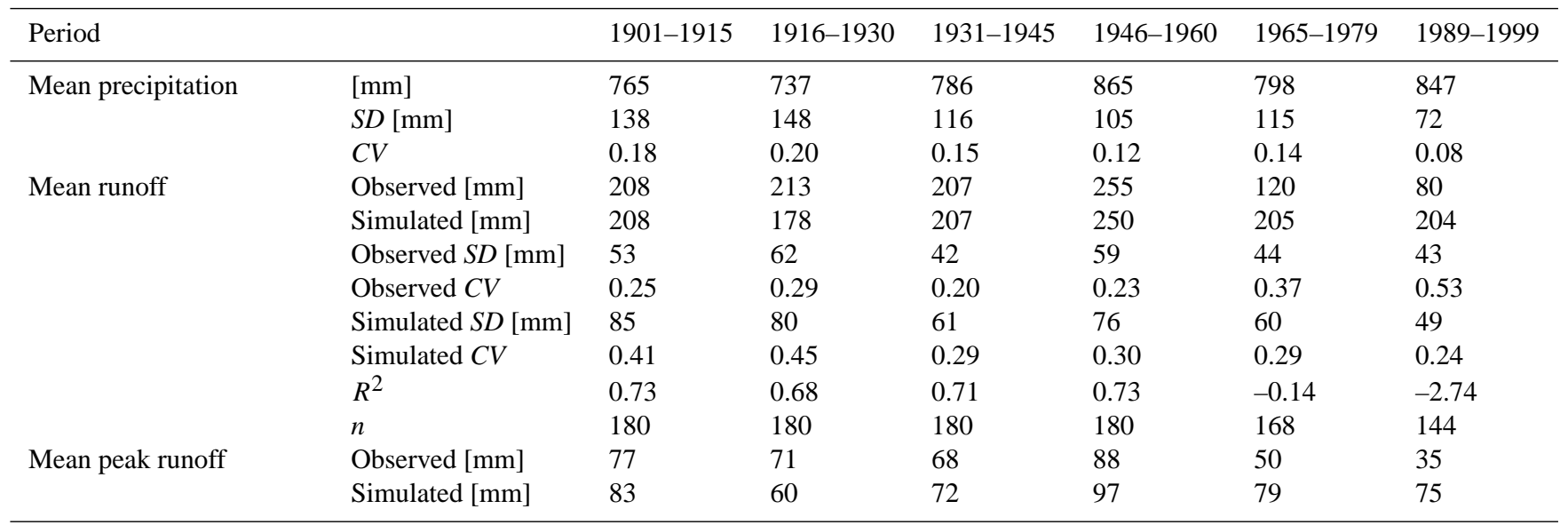

\subsection{Calibration and validation}

First, the model was calibrated and validated. We assumed a baseline period between 1901 and 1915 for which the model was calibrated. Periods of 15 years were chosen, as this leaves a number of periods before the 1960s (after which major reservoirs were built) for which the model performance can be assessed. The calibration of the model involved the adjustment of a reduction factor that tunes the reference evaporation (see Eq. A5), a coefficient that determines the separation between groundwater and runoff (Eq. A2), and a recession coefficient that determines the delay of the groundwater flow (Eq. A4). The calibration involved the match to observed total annual river runoff, as well as seasonal patterns. The performance of the model was tested at every stage using the efficiency coefficient $R^{2}$ from Nash and Sutcliffe (1970). After the model was calibrated for the period 1901-1915, the following five 15-year periods for which observed data were available were used to validate the model. The model was able to closely match the observed average annual river runoff (see Table 1). The model results for the period 1901-2000 are shown in Fig. 4, together with the observed runoff. By comparing the observed runoff with the simulated runoff for the remaining 15 -year periods the model performance was assessed. The model efficiency coefficient after calibration of $R^{2}=0.73$ for the period 1901-1915 indicates that the model is capable of reasonably estimating mean monthly runoff for a total of 180 months, in particular when taking into account the high degree of human intervention in the hydrological cycle in this basin. Already during the period 1901-1915 many (small) reservoirs are present in the basin. The coefficient of determination $\left(r^{2}\right)$ between observed and simulated monthly runoff is 0.77 for the pe-

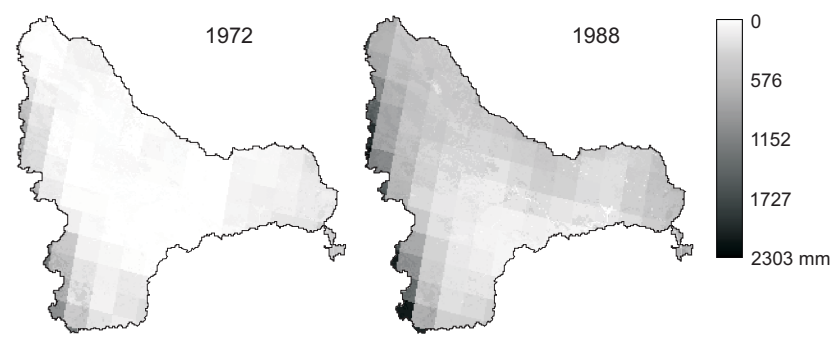

Fig. 5. Effective precipitation over the Krishna river basin for the years 1972 and 1988.

riod 1901-1915 $(n=180)$ and 0.75 for the period $1901-1960$ ( $n=720$ ). The efficiency coefficient $R^{2}=0.68$ for the period 1916-1930 is slightly lower than the coefficient for the calibration period (Table 1), but the performance of the model for the two following periods (1931-1945 and 1946-1960) is sufficient to assume the model is accurately describing the runoff during these periods $\left(R^{2}=0.71\right.$ and $R^{2}=0.73$ respectively). During the last two simulated periods (1965-1979 and 1989-1999) the fit of the model to the observed data is not good, as can be seen from the negative model efficiency coefficients in Table 1.

Annual maximum monthly river runoff is approached reasonably only in absolute terms for the period 1901-1960, as can be seen from Fig. 4 (bottom); the coefficient of determination $\left(r^{2}\right)$ between observed and simulated maximum runoff is only 0.25 for the period $1901-1960$. The simulations of 1960 and beyond act as a reference to detect the changes in the hydrological cycle. The supposed reason for the discrepancy is a result of the fact that certain changes, such as the construction reservoirs, are not captured by the simulation. 
Table 2. Top five of simulated annual effective precipitation (defined as precipitation minus actual evaporation) averaged over the Krishna river basin.

\begin{tabular}{llll}
\hline Year & Driest & & Wettest \\
& Effective precipitation $[\mathrm{mm}]$ & Year & 546 \\
1918 & 97 & 1903 & 525 \\
1972 & 97 & 1956 & 489 \\
1920 & 98 & 1975 & 472 \\
1985 & 1916 & 453 \\
1987 & 141 & 1964 & \\
\hline
\end{tabular}

Furthermore, one of the advantages of the STREAM model is that it can generate spatial output of different variables. Figure 5 shows the effective precipitation (total annual precipitation minus actual evaporation) for the extreme dry year of 1972 and the moderate wet year of 1988. During 1972 very little water was available and in particular the basin interior was extremely dry. The five driest and wettest years in terms of effective precipitation, as simulated by the model, are listed in Table 2. The average amount of effective precipitation in the period 1901-2000 was $278 \mathrm{~mm}$. The amount that was available in 1918 was only $35 \%$, while the amount that was available in 1903 was 197\% of the average amount. Clearly, variation in precipitation can lead to considerable changes in the amount of water that is available for vegetation and humans.

4.3 Impacts on average annual runoff and maximum monthly runoff

There is a clear deviation of the simulated river runoff with respect to the observed runoff after 1960, for both the total annual runoff and the maximum monthly runoff (Fig. 4). Although there were very little changes in total annual precipitation, there is a clear reduction in annual average runoff of approximately $84 \mathrm{~mm} \mathrm{(41 \% )} \mathrm{and} 123 \mathrm{~mm}(61 \%)$ and a reduction in the maximum monthly runoff of approximately $29(37 \%) \mathrm{mm}$ and $40 \mathrm{~mm}(53 \%)$ over the periods 1965-1979 and 1989-1999, respectively (Table 1). These values were calculated by subtracting the observed river runoff from the simulated runoff. A t-test was applied in order to determine whether there is a significant change in observed river runoff during the period 1965-1979, relative to the period 19011960. It turns out that the mean annual river runoff has significantly changed already during this period (test value $\left.t=7.214, t_{\text {crit }}=3.460, p<0.0001\right)$.

The hydrological model was able to simulate the relative changes in river runoff variability over the 15 -year periods, although in absolute terms the model overestimated the variability (Table 1). The coefficient of variation (CV), defined as the standard deviation divided by the mean runoff, has been estimated approximately 1.5 times higher than the observed
CV for the periods between 1901 and 1960. This difference is likely caused by the fact that the STREAM model is too sensitive to changes in precipitation. This in turn could result from the fact that certain storage processes in the model, such as groundwater, and soil moisture, are represented in a simplified form. The variability in annual river runoff follows very closely the changes in the variability of the total annual precipitation, until the period 1946-1960. After this period the observed variability in river runoff increased, and by an amount that is higher than would be expected on the basis of the model results that were forced by the variability in precipitation only. Instead of a CV of approximately 0.29 and 0.24 over the periods 1965-1979 and 1989-1999, as simulated by the hydrological model, the $\mathrm{CV}$ in runoff increased to 0.37 and 0.53 over the periods $1965-1979$ and 1989-1999, respectively. Assuming that the model would also overestimate the CV by $50 \%$ in the periods 1965-1979 and 1989-1999, as in the period 1901-1960 (see above), the CV may have only been 0.20 and 0.16 over the periods 1965 1979 and 1989-1999, respectively. It appears therefore that two thirds of the current variability in runoff (as defined by the $\mathrm{CV}$ ) is caused by the decline in total runoff.

\subsection{Impacts on seasonal runoff}

Next, we simulated the difference between observed and modelled river runoff for the different monsoon seasons. In Fig. 6 the relative difference between the simulated and observed annual river runoff over the period 1901-1979 is plotted against time for the monsoon season (June-November) and the post-monsoon (December-May). This relative difference $d$ was calculated as

$d=\frac{Q_{\mathrm{obs}}-Q_{\mathrm{sim}}}{Q_{\mathrm{sim}}}$

where $Q_{\text {obs }}$ is the simulated amount of river runoff and $Q_{\text {sim }}$ the observed amount of runoff in a particular year.

A steady decline in river runoff during the monsoon season started around the beginning of the 1960s (Fig. 6, top). During the period 1965-1979 on average approximately half the runoff that is simulated was actually observed. This 
decreased further to approximately less than a third on average over the period 1991-2000. An all-time low occurred during the year 1995, when only $10 \%$ of the estimated river runoff was observed. The opposite pattern can be seen for the post-monsoon season. Overall, observed river runoff during the post-monsoon season increased relative to what is estimated by the model, except for the period 1970-1974 when very little of the available water reached the outflow point. During the period $1965-1979$ on average 1.5 times more river runoff is observed than is expected on the basis of the model simulation (Fig. 6). This increased further during the period 1989-1999 to about three times the simulated river runoff. In the year 1992 ten times the simulated river runoff was observed during the post-monsoon season.

The difference between the simulated and observed river runoff will reflect environmental impacts other than observed climate variability, since the variability in precipitation is accounted for in both the observed and simulated runoff. The difference is probably mainly due to the obstruction of the river channel by dams and increasing water consumption. The timing of the change in the relative difference supports this, as it coincides with the increase in reservoir capacity in the basin, as seen in Fig. 3. During the monsoon season (June-December), water is captured for irrigation, resulting in a decline in river runoff. During the post-monsoon season (December-May), a second cropping season may occur in irrigated areas, for which reservoir water is used. This results in a slight increase in base flow during the post-monsoon season, as there is an increasing amount of return flow. The reservoirs, their operation and the increasing water consumption are reflected in an overall reduced and more variable outflow at the lower end of the river basin.

\section{Accounting for increasing water consumption}

In previous sections we discussed the model results that incorporated only climate variability and compared these with the observed record. We now attempt to simulate the impact of increasing reservoir development and associated water consumption on the river runoff. Changes in water consumption were assumed to be reflected in the difference between the simulated and observed river runoff, as explained in the previous section. We calculated the ratio between simulated and observed river runoff over the period 1965-1979 and used these as attenuation factors. Next, we derived a function of reservoir development, by comparing the reservoir capacity in a particular year with the average reservoir capacity between 1965 and 1979. These functions were then used to subtract a particular amount from the runoff as simulated by the water balance model. We chose to subtract amounts that are stored in reservoirs and used for irrigation at the river basin end. We used the equations

for $R_{y} \leq 1, Q_{\text {sim }, i}^{\prime}=Q_{\text {sim }, i}-Q_{\text {sim }, i}\left(1-f_{j}\right) R_{y}$
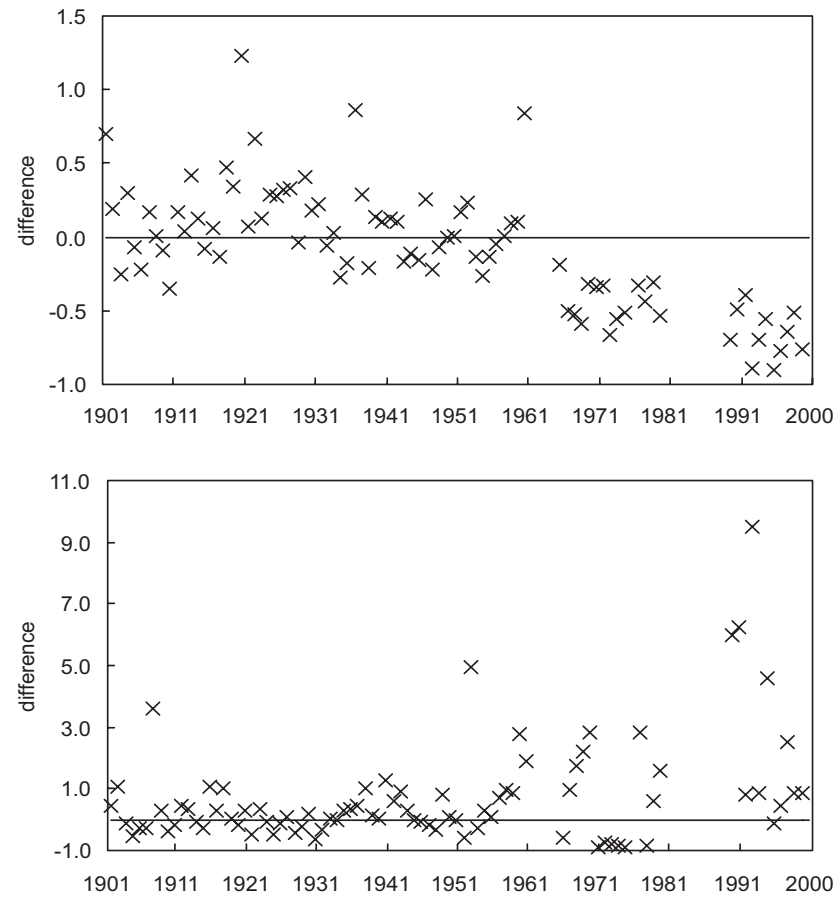

Fig. 6. Relative difference between the observed and simulated river runoff during the monsoon season (top) and the post-monsoon season (bottom).

for $R_{y}>1, Q_{\mathrm{sim}, i}^{\prime}=Q_{\mathrm{sim}, i} f_{j} / R_{y} D$

where $R_{y}$ is the reservoir capacity in year $y$, normalised to the period 1965-1979, $Q_{\mathrm{sim}, i}^{\prime}$ is the adjusted simulated river runoff in month $i$ in millimetres, $Q_{\mathrm{sim}, i}$ is the original simulated runoff in month $i$ in millimetres, $f_{j}=\bar{Q}_{\mathrm{obs}, j} / \bar{Q}_{\mathrm{sim}, j}$ with average observed and simulated runoff in month $j(j$ is 1 to 12) for the period 1965-1979 in millimetres and $D$ is a damping factor. We used a damping factor since it is expected that a certain increase in reservoir capacity will not result in a proportionate reduction in river runoff, as part of the irrigation water is rerouted to the river channel as return flow. This is evident from the fact that although the reservoir capacity continued to increase approximately threefold relative to the period 1965-1979 (Fig. 3), river runoff did not decrease to a third of the previous period (see Table 1). This damping factor corrects the additional expected evaporation, which is not taken into account by STREAM water balance model. Rather than a full simulation of the impacts of the reservoirs, Eqs. (2) and (3) correct the total runoff $Q$ as simulated by the model (see Appendix A). The value of the damping factor was set at 0.84 , as this provided the best Nash-Sutcliffe efficiency coefficient values for the periods 1965-1979 and 1989-1999.

Figure 7 depicts the results of the simulation, incorporating the effect of reservoirs. The fit of the simulated river runoff to the observed data is better, for both the total annual runoff and the maximum monthly runoff. The model 
Table 3. Observed average amount of annual precipitation and its coefficient of variation, observed and simulated total average annual river runoff (in millimetres), their standard deviations $(S D)$, coefficients of variation $(C V)$ and model efficiency coefficients $\left(R^{2}\right)$ for the different periods. $n$ designates the number of months that were used to calculate the $C V$ and $R^{2}$ of the runoff. The simulation incorporates an increase in reservoir capacity.

\begin{tabular}{|c|c|c|c|c|c|c|c|}
\hline Period & & 1901-1915 & 1916-1930 & 1931-1945 & 1946-1960 & 1965-1979 & 1989-1999 \\
\hline Mean precipitation & $S D[\mathrm{~mm}]$ & 138 & 148 & 116 & 105 & 115 & 72 \\
\hline \multirow[t]{6}{*}{ Mean runoff } & Observed [mm] & 208 & 213 & 207 & 255 & 120 & 80 \\
\hline & Simulated [mm] & 205 & 172 & 195 & 217 & 127 & 65 \\
\hline & Observed $S D[\mathrm{~mm}]$ & 53 & 62 & 42 & 59 & 44 & 43 \\
\hline & Simulated $C V$ & 0.41 & 0.45 & 0.29 & 0.27 & 0.32 & 0.24 \\
\hline & $R^{2}$ & 0.73 & 0.68 & 0.73 & 0.73 & 0.69 & 0.41 \\
\hline & $n$ & 180 & 180 & 180 & 180 & 168 & 144 \\
\hline \multirow[t]{2}{*}{ Mean peak runoff } & Observed [mm] & 77 & 71 & 68 & 88 & 50 & 35 \\
\hline & Simulated [mm] & 82 & 58 & 69 & 87 & 55 & 27 \\
\hline
\end{tabular}
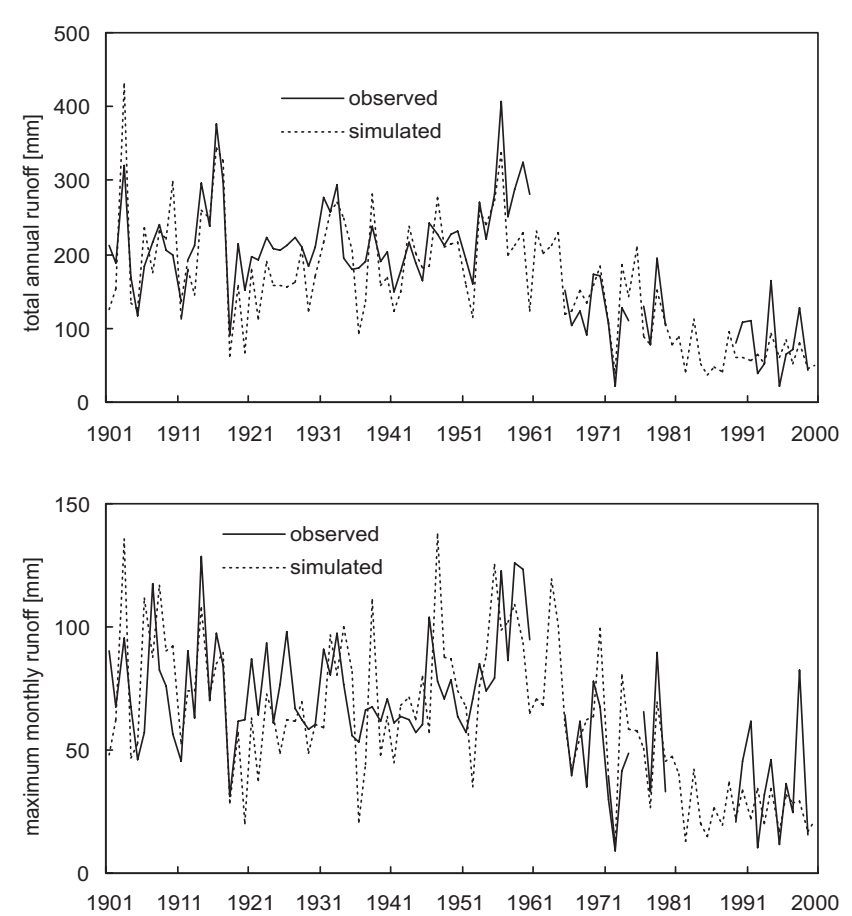

Fig. 7. Simulation model results, incorporating increasing water use, for the period 1901-2000 compared to the observed total annual river runoff (top) and maximum monthly river runoff (bottom).

efficiency coefficients have improved relative to the model without reservoirs. For the period 1965-1979 the model fits well $\left(R^{2}=0.69\right)$, while for the period 1989-1999 the model has improved considerably $\left(R^{2}=0.41\right)$ (see Table 3 ). The model still could not approach the increase in variability of the total annual river runoff that is observed during the periods 1965-1979 and 1989-1999. The observed variability could be a result of factors that are not included in the model, such as reservoir operation and timing of irrigation.

The estimated amount of water that is additionally evaporated is plotted in Fig. 8 and includes evaporation from evaporation due to irrigation using water from the major reservoirs, including the evaporation from these reservoirs. The estimate of additional evaporation was obtained by computing the difference between adjusted and original annual river runoff $Q_{\text {sim }}^{\prime}$ and $Q_{\text {sim. }}$. Note that these amounts are additional to amounts extracted by tanks and reservoirs constructed prior to 1901, which are incorporated in the "natural' vegetation evaporation estimate. Until 1953 a negligible amount of water was deviated from the main river. During the period 1965-1979 an average of $78 \mathrm{~mm}$ (38\% of simulated river runoff) was extracted. This estimated amount compares well with the estimated decline of $84 \mathrm{~mm}$ that was reported in Sect. 4.3. Additional water consumption increased to $139 \mathrm{~mm}$ (68\% of simulated runoff) during the period 1989-1999. This amount is higher than the estimated decline of $123 \mathrm{~mm}$ reported in Sect. 4.3. This difference is probably caused by the rough estimation of water extraction, based on reservoir capacity increase only, using Equation 3. Variations in reservoir operation are not taken into account. The estimate of Sect. 4.3 using the difference between observed and simulated river runoff for the period 1989-1999 of $123 \mathrm{~mm}$ may be more accurate. 


\section{Discussion and conclusions}

The construction of reservoir capacity in the Krishna river basin during the second half of the 20th century has been considerable. Our analysis has shown that observed downstream river runoff in the Krishna river basin exhibited a strong decline after 1960. At the same time, peak discharges decreased substantially.

Using a hydrological model we were able to simulate the pristine situation, as well as spatial aspects of components of the hydrological cycle. The river runoff as estimated by the water balance model deviates from the observed discharges, in particular during the period after 1960. This difference is attributed to increasing water consumption. An analysis of the difference between simulation and observation shows that a structural decline in the total average annual runoff of $123 \mathrm{~mm}$ (or $61 \%$ of simulated runoff) over the period 1989 1999 can be attributed to factors other than climate variability or climate change. This finding is confirmed by previous observations that increasing global irrigation water requirements have lead to considerable reductions of natural discharges (e.g. Döll and Siebert, 2002). During the monsoon season a decline of an average $121 \mathrm{~mm}(67 \%)$ was observed and during the post-monsoon season an average relative increase in runoff of $8 \mathrm{~mm}(296 \%)$ was observed over the period 1989-1999. This estimated increase in base flow during the post-monsoon season is supported by observed cropping and irrigation activities during this period. Irrigation in double-cropped irrigated areas fed by water from large reservoirs was seen during field visits in the downstream area of the Krishna river basin and from independent observations using remote sensing of vegetation phenology (Biggs et al., 2006).

The increasing water consumption was also simulated using the record of reservoir construction and the water balance model results. From these data it is estimated that increasing water consumption for irrigation and hydropower has contributed to approximately $134 \mathrm{~mm}$ extra evaporation annually in the last 10 years (1991-2000), which is about $21 \%$ of total annual evaporation and $68 \%$ of annual river runoff in the basin as simulated by the hydrological model. These estimated increases are in general agreement with previous observations for evaporation increases due to irrigation in other river basins (Haddeland et al., 2006).

Changes in precipitation due to climate variability alone resulted in very little variation in river runoff during the period 1901-1960. Observed climate variability accounts for changes in annual river runoff of up to approximately +34 (15\%) and $-14 \mathrm{~mm}(6 \%)$ during the period 1901-1960. Variability in river runoff (coefficient of variation of 0.20 to 0.25 ) changed little over the period 1901-1960 in response to variation in precipitation. In fact, variability in precipitation appears to have decreased over time (coefficient of variation of 0.18 in 1901-1915 to 0.08 in 1989-1999. Without increasing water consumption, river runoff would have remained the

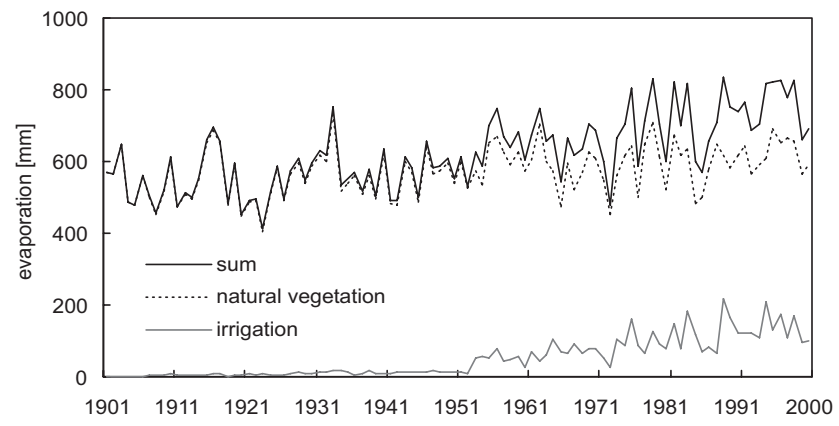

Fig. 8. Simulated evaporation by the natural vegetation, estimated additional water consumption for irrigation, and their sum.

same over the period of study, and variability would have decreased to about one third of the current observed runoff variability that is at 0.53 . These estimates were obtained using a model simulation without including reservoirs.

It is not possible to estimate the contribution of anthropogenic climate change to the observed climate variability (which in this study is defined to include both natural variability and anthropogenic climate change). For this, a study is needed to attribute climatic changes to greenhouse gas forcing, using climate models. Such regional attribution studies have been performed for regional temperature changes (Stott, 2003). These studies suggest that uncertainties of attribution of temperature changes increase with reduction in spatial scale. Signals of human induced climate change in precipitation records are particularly difficult to detect (IDAG, 2005), especially at this relatively small scale. The changes in runoff of the Krishna river basin and its variability over the last century are therefore likely to be due only to human interference and not to climate variability. However, severe events, such as the drought in 1972, are a direct consequence of shortfalls in precipitation. Changes in future climate may therefore have far-reaching effects in downstream areas, when more frequent dry periods compound with structural declines in river runoff as a result of increasing consumption upstream.

The results of our research imply that when analysing the impact of climate variability, and also in analysing the impact of climate change, other environmental changes can be equally or more important. It is possible, however, to account for such changes, using the methods described above. The model can also be used to estimate the sensitivity to future climate change, using scenarios. The methods are fairly simple, but can clearly separate between different environmental changes, such as reservoir construction and water consumption. Moreover, other methods that assess temporal changes in water consumption and evaporation also rely on the availability of data. Remote sensing methods that estimate variation in evaporation for instance, need satellite data that are available only since the late 1970s. Water balance models offer a useful tool to estimate changes before that point in 
time. One condition for using this method, however, is that a discharge record and a record of climate parameters of sufficient length are available that can be compared to model output. Future studies may need to take into account other changes, such as land use change, and changes in evaporation that were only roughly estimated in this study.

\section{Appendix A}

\section{STREAM model formulation}

The STREAM model calculates the water balance for each cell in a grid at a monthly time step according to a number of parameters (Aerts et al., 1999). Total river runoff $Q$ is calculated as

$Q=R+M+B$

where $R$ is direct runoff, $M$ is snow melt, and $B$ is the base flow origination from groundwater, all in $\mathrm{mm}$ per month.

The direct runoff $R$ is calculated from the soil water balance $S$ using a separation coefficient $s_{c}$ :

$R=S \cdot s_{c}$

The remaining amount of water from the soil water balance is redirected to the groundwater $(T G)$, using

$T G=S-R$

The base flow is calculated from the amount of groundwater $G W$ stored using a recession coefficient $r_{c}$ :

$B=G W / r_{c}$

The soil water balance and actual evaporation are calculated for each month using the equations from Thornthwaite and Mather (1957). Actual evaporation is estimated from adjusted reference evaporation, using a crop factor $k_{c}$ and a reduction coefficient $F_{\text {red }}$ that acts as calibration factor:

$E T_{0}^{\prime}=E T_{0} \cdot k_{c} \cdot F_{\text {red }}$

Reference evaporation is calculated from temperature, using the formulas from Thornthwaite (1948). FAO factors were used for adjusting the reference evaporation to different land-cover types using crop factors (Doorenbos and Pruitt, 1975). Land-cover classes at a resolution of 1 by $1 \mathrm{~km}$ were taken from the Global Land Cover Characteristics database Version 1.2, produced by the International Geosphere Biosphere Programme (IGBP). This dataset is based on NOAA AVHRR satellite observations from April 1992 to March 1993, which were classified to land-cover characteristics by Belward et al. (1999). Parameters for the maximum soil water holding capacity were taken from a global dataset compiled by the United States Department of Agriculture (available from http://soils.usda.gov/use/worldsoils/ mapindex/whc.html) with a resolution of 2 arc minutes (about 3.5 by $3.5 \mathrm{~km}$ ).
Acknowledgements. We thank the Climatic Research Unit for providing the TS 2.0 climate dataset. G. van de Coterlet is thanked for converting these data into GIS format. We thank three anonymous referees who provided constructive comments that helped to improve this paper. This study was supported by the Dutch Ministry of Transport, Public Works and Water Management through the Coastal Zone Management Centre of the National Institute for Coastal and Marine Management (RIKZ), and by the NIVR/SRON/NWO User Support Programme 2. All errors and opinions remain ours.

Edited by: B. van den Hurk

\section{References}

Aerts, J. C. J. H., Kriek, M., and Schepel, M.: STREAM, spatial tools for river basins and environment and analysis of management options: set up and requirements, Phys. Chem. Earth Part B, 24, 591-595, 1999.

Aerts, J. C. J. H., Hassan, A., Savenije, H. H. G., and Khan, M. F.: Using GIS tools and rapid assessment techniques for determining salt intrusion: STREAM, a river basin management instrument, Phys. Chem. Earth Part B, 25, 265-273, 2000.

Alcamo, J., Döll, P., Kaspar, F., and Siebert, S.: Global change and global scenarios of water use and availability: an application of WaterGAP 1.0. Report A9701, Centre for Environmental Systems Research, University of Kassel, Kassel, 1997.

Arnell, N. W.: Relative effects of multi-decadal climatic variability and changes in the mean and variability of climate due to global warming: future streamflows in Britain, J. Hydrol., 270, 195213, 2003.

Arnell, N. W, Liu, C., Compagnucci, R., et al.: Hydrology and water resources, in: Climate Change 2001: Impacts, Adaptation and Vulnerability. Contribution of Working Group II to the Third Assessment Report of the Intergovernmental Panel on Climate Change, edited by: McCarthy, J. J., Canziani, O. F., Leary, N. A., Dokken, D. J., and White, K. S., Cambridge University Press, Cambridge, 191-233, 2001.

Belward, A. S., Estes, J. E., and Kline, K. D.: The IGBP-DIS global $1 \mathrm{~km}$ land cover data set DISCover: a project overview, Photogrammetric Eng. Remote Sens., 65, 1013-1020, 1999.

Biggs, T. W., Thenkabail P. S., Gumma, M. K., Scott, C. A., Parthasaradhi, G. R., and Turral, H. N.: Irrigated area mapping in heterogeneous landscapes with MODIS time series, ground truth and census data, Krishna Basin, India, Int. J. Remote Sens., in press, 2006.

Burn, D. H. and Hag Elnur, M. A.: Detection of hydrologic trends and variability, J. Hydrol., 255, 107-222, 2002.

Changnon, S. A. and Demissie, M.: Detection of changes in streamflow and floods resulting from climate fluctuations and land-use drainage changes, Climatic Change, 32, 411-421, 1996.

Doorenbos, J. and Pruitt, W. O.: Guidelines for predicting crop water requirements, Irrigation and Drainage Paper No. 24, Food and Agricultural Organisation, Rome, 1975.

Döll, P. and Siebert, S.: Global modeling of irrigation water requirements, Water Resour. Res., 38, 1037, 2002.

Falkenmark, M. and Lannerstad, M.: Consumptive water use to feed humanity: curing a blind spot, Hydrol. Earth Syst. Sci., 9, 15-28, 
2005 ,

http://www.hydrol-earth-syst-sci.net/9/15/2005/.

Haddeland, I., Lettenmaier D. P., and Skaugen, T.: Effects of irrigation on the water and energy balances of the Colorado and Mekong river basins, J. Hydrol., 324, 210-223, 2006.

Herschy, R.: World Catalogue of Maximum Observed Floods, Publication 184, Int. Assoc. Hydrol. Sci., Wallingford, 2003.

IDAG: Detecting and attributing external influences on the climate system: a review of recent advances, J. Climate, 18, 1291-1314, 2005.

Krishnamurthy, V. and Shukla, J.: Intraseasonal and interannual variability of rainfall over India, J. Climate, 13, 4366-4377, 2000.

Kundzewicz, Z. W. and Robson, A. J.: Change detection in hydrological records - a review of the methodology, Hydrol. Sci. J., 49, 7-19, 2004.

Letcher, R. A., Schreider, S. Y., Jakeman, A. J., Neal, B. P., and Nathan, R. J.: Methods for the analysis of trends in streamflow due to changes in catchment condition, Environmetrics, 12, 613630, 2001

Magilligan, F. J., Nislow, K. H., and Graber, B. E.: Scaleindependent assessment of discharge reduction and riparian disconnectivity following flow regulation by dams, Geology, 31, 569-572, 2003.

Meybeck, M.: Global analysis of river systems: from Earth system controls to Anthropocene syndromes, Philosophical Transactions of the Royal Society of London Series B, 358, 1973-1984, 2003.

Middelkoop, H., Daamen, K., Gellens, D., Grabs, W., Kwadijk, J. C. J., Lang, H., Parmet, B. W. A. H., Schädler, B., Schulla, J., and Wilke, K.: Impact of climate change on hydrological regimes and water resources management in the Rhine Basin, Climatic Change, 49, 105-128, 2001.

Mitchell, T. D. and Jones, P. D.: An improved method of constructing a database of monthly climate observations and associated high-resolution grids, Int. J. Climatol., 25, 693-712, 2005.

Munot, A. A. and Kothawale, D. R.: Intra-seasonal, inter-annual and decadal scale variability in summer monsoon rainfall over India, Int. J. Climatol., 20, 1387-1400, 2000.

Nash, J. E. and Sutcliffe, J. V.: River flow forecasting through conceptual models part I: a discussion of principles, J. Hydrol., 10, 282-290, 1970.

Nilsson, C., Reidy, C. A., Dynesius, M., and Revenga, C.: Fragmentation and flow regulation of the world's large river systems, Science, 308, 405-408, 2005.

Ramesh, R. and Subramania, V.: Temporal, spatial and size variation in the sediment transport in the Krishna River basin, India, J. Hydrol., 98, 53-65, 1988.

Rockström, J., Axberg, G. N., Falkenmark, M., Lannerstad, M., Rosemarin, A., Caldwell, I., Arvidson, A., and Nordström, M.: Sustainable pathways to attain the millennium development goals; assessing the key role of water, energy and sanitation, Stockholm Environment Institute, Stockholm, 2005.

Rodier, J. A. and Roche, M.: World Catalogue of Maximum Observed Floods, Publication 143, Int. Assoc. Hydrol. Sci., Wallingford, 1984.
Rosnay, P. de, Polcher, J., Laval K., and Sabre, M.: Integrated parameterization of irrigation in the land surface model ORCHIDEE. Validation over Indian Peninsula, Geophys. Res. Lett., 30, 1986, 2003.

Schreider, S. Y., Jakeman, A. J., Letcher, R. A., Nathan, R. J., Neal, B. P., and Beavis, S. G.: Detecting changes in streamflow response to changes in non-climatic catchment conditions: farm dam development in the Murray-Darling basin, Australia, J. Hydrol., 262, 84-98, 2002.

Sekhar, M. C. and Indira, Ch.: Modelling chloride-discharge relationships in Krishna river basin, Water Sci. Technol., 48, 57-63, 2003.

Stott, P. A.: Attribution of regional-scale temperature changes to anthropogenic and natural causes, Geophys. Res. Lett., 30, 1728, 2004.

Syvitski, J. P. M., Vörösmarty, C. J., Kettner, A. J., and Green, P.: Impact of humans on the flux of terrestrial sediment to the global coastal ocean, Science, 308, 376-380, 2005.

Tharme, R. E.: A global perspective on environmental flow assessment: emerging trends in the development and application of environmental flow methodologies for rivers, River Res. Appl., 19, 397-441, 2003.

Thornthwaite, C. W.: An approach toward a rational classification of climate, The Geographical Review, 38, 55-94, 1948.

Thornthwaite, C. W. and Mather, J. R.: Instructions and tables for computing potential evapotranspiration and the water balance, Publications in Climatology, 10, 183-243, Laboratory of Climatology, Drexel Institute of Technology, Centerton, New Jersey, 1957.

Van Deursen, W. P. A. and Kwadijk, J. C. J.: Rhineflow: an integrated GIS water balance model for the river Rhine, in: Application of Geographic Information Systems in Hydrology and Water Resources Management, edited by: Kovar, K. and Nachtnebel, H. P., Publication 211, Int. Assoc. Hydrol. Sci., Wallingford, 507-519, 1993.

Van Deursen, W. P. A. and Kwadijk, J. C. J.: The impacts of climate change on the water balance of the Ganges-Brahmaputra and Yangtze Basin, Report RA94-160, Resource Analysis, Delft, 1994.

Vörösmarty, C. J., Fekete, B., and Tucker, B. A.: Global river discharge, 1807-1991, version 1.1 (RivDIS dataset), Institute for the Study of Earth, Oceans, and Space, University of New Hampshire, Durham NH, 1998.

Vörösmarty, C. J., Green, P., Salisbury, J., and Lammers, R. B.: Global water resources: vulnerability from climate change and population growth, Science, 289, 284-288, 2000.

Wallach, B.: Irrigation developments in the Krishna Basin since 1947, The Geographical Review, 74, 127-144, 1984.

Wallach, B.: British irrigation works in India's Krishna Basin, J. Historical Geography, 11, 155-174, 1985.

Winsemius, H. C., Savenije, H. H. G., Gerrits, A. M. J., Zapreeva, E. A., and Klees, R.: Comparison of two model approaches in the Zambezi river basin with regard to model reliability and identifiability, Hydrol. Earth Syst. Sci., 10, 339-352, 2006, http://www.hydrol-earth-syst-sci.net/10/339/2006/. 